\title{
Bamboo availability and utilization potential as a building material
}

\begin{abstract}
Bamboo is a grass found easily on almost all continents with special ability to grow on wasteland as well. The resources of bamboo are wide and available globally with China and India contributing to the maximum world bamboo forest. Due to its special unique features, there is a great demand for bamboo and its product in the market. The tensile strength of bamboo ( 28,000 pounds per square inch), is much higher than steel $(23,000$ pounds per square inch). The utilization potential of bamboo is enormous. The present paper discusses an overview of special properties of bamboo and its utilization potential. Opportunities and threats to the market of bamboo are also discussed.
\end{abstract}

Keywords: bamboo, properties, tensile strength, compressive strength, utilization potential, decay resistance
Volume 2 Issue 5 - 2018

Perminder Jit Kaur

Centre for Rural Development and Technology, Indian Institute of Technology, India

Correspondence: Perminder Jit Kaur, Centre for Rural Development and Technology, Indian Institute of Technology, Delhi, India,Tel +93 I I 4 I74 0I, Email perminder.dua@gmail.com

Received: November 21, 2017 | Published: September 07, 2018

\section{Introduction}

Bamboo is a grass belonging to Gramineae family, distributed in tropical, subtropical and mild temperate zones between approximately $46^{\circ}$ north and $47^{\circ}$ south latitude. There are more than 90 genera of bamboo divided into about 1,200 species. ${ }^{1}$ Bamboo is commonly found in Africa, Asia, some parts of Europe and America.

Globally, bamboo is widely available in about 1662 species and 121 genera. It is distributed over a large number of biogeographic regions. There is large variation in the properties of bamboo species among species. On one side there is the dwarf herbaceous species found in the regions with a temperate climate and on the other side, giant woody bamboo species are found in temperate climates with height upto $20 \mathrm{~m}^{2}$

Bamboo forest is distributed across about 31.5 million ha of land, which is approximately $0.8 \%$ of the global forest area. ${ }^{3,4}$ India and China contributes a major proportion to the total world's bamboo forest land. It is reported that about 500-534 species of bamboo are found in China with a total of approximately 4.84-5.71 million ha bamboo forest land. ${ }^{3,4}$ In India, the bamboo forest area is 13.96 million ha with 123 species in 23 genera. ${ }^{5}$ Bamboo forests are found mainly ( $80 \%$ of total area) in Asia-pacific region. ${ }^{1}$

\section{Socio-environmental values}

Socio-environmental values associated with bamboo make it an alternative material for housing, handicraft etc. Bamboo is used in pulp and paper industry. The hollow internal structure of bamboo culms makes it light weight, easy to work with and convenient to transport. Bamboo is used not only to produce high end value added commodities like laminated panels, boards, pulp and paper, prefabricated houses, biomass, biofuel, fiber based articles, stalk fiber, but also a valuable source for food and the neutraceutical industry.

The hardened culm of bamboo can perform functions equivalent to woody stems of many tree species. ${ }^{8}$ Its high growth rate, versatility of uses makes it superior to many species of plants in building and construction industry. In addition to this, its leaves can be used for fodder, shoots can provide food for the human population. According to an estimate around 2.5 billion people have a direct dependence on bamboo for their survivals. ${ }^{8}$
The Bamboo plant is also found to be an excellent source as a carbon sink and effective in the mitigation of the greenhouse effect. ${ }^{9}$ Bamboo plant helps to conserve soil and assist in the preservation of biodiversity. The utilization of this natural resource by the rural people provides the solution to rural poverty and unemployment. This helps not only in environmental protection but also provide livelihood to rural artisans. Using their skills and capabilities, artisans can prepare various simple items using bamboos, which can attract high value in rural and urban markets. ${ }^{10}$ In addition to building material, it can be used by the local community for making fences, ladders, handicraft items, utensils, etc. When planted around ponds as watershed, bamboo can help to decrease the evaporation of water from ponds, thus help in water conservation. Bamboo leaves can be used as a sources of organic manure, reducing the cost of fertilizers. ${ }^{11}$

\section{Special properties of bamboo}

Processing of bamboo being simple requires no special skill and equipment leading to low initial investment.

Compared to steel, concrete and timber, the light weight of bamboo is able to withstand more loads. Bamboo is one of the strongest building materials. The tensile strength of bamboo $(28,000$ pounds per square inch), is much higher than steel ( 23,000 pounds per square inch). It is reported that 50 times less energy is required to generate 1 $\mathrm{m}^{3}$ per unit stress for bamboo as structural materials as compared to steel or concrete. This makes bamboo a suitable alternative to steel in load bearing applications (Table 1). ${ }^{12}$

High flexibility and growth rate, low weight to height ratio, provides bamboo extensive opportunities as building material. Hollow design is structurally superior to woody stem of timber. Density of bamboo species varies between 700 and $800 \mathrm{~kg} / \mathrm{m} 3$. This is an important factor to be considered for building designs. Bending stress at failure is 0.14 times mass per unit volume. The high value of mass per unit volume of bamboo provides its greater bending strength at failure.

The bamboo culm can be considered as a cylindrical shell. Transversal diaphragms divide the culm at the nodes. Bamboo shells are orthotropic materials. It can bear more stress in the direction parallel to the fibers, while capacity to hold stress is lower in perpendicular direction to the fibers. Bamboo culm consists of long 
and parallel fibers of cellulose embedded in the matrix of lignin. The distribution of fibers is closer in the outer part, providing it more strength under high load bearing applications and wind forces. ${ }^{13}$ The fibers are concentrated in regions closer to the outer skin. This is consistent with the state of stress distribution when the culm is subjected to wind forces.

Table I Specific properties of bamboo

\begin{tabular}{lll}
\hline Property & Value & Reference \\
\hline Starch content & $2-4.5 \%$ & Kaur et al. ${ }^{16}$ \\
Density & 0.2 to 0.85 & Kaur et al. ${ }^{16}$ \\
Lignin & $20-27 \%$ & Kaur et al. ${ }^{16}$ \\
Ligno-cellulose & $46-57 \%$ & Kaur et al. ${ }^{16}$ \\
$\begin{array}{l}\text { Modulus of rupture- } \\
\text { Modulus of Elasticity }\end{array}$ & 610 to $1600 \mathrm{~kg} / \mathrm{cm}^{2}$ & Dange \& Pataskar ${ }^{20}$ \\
$\begin{array}{l}\text { Ultimate compressive } \\
\text { stress }\end{array}$ & 794 to $864 \mathrm{~kg} / \mathrm{cm}^{2}$ & Dange \& Pataskar ${ }^{20}$ \\
$\begin{array}{l}\text { Safe working stress in } \\
\text { compression }\end{array}$ & $105 \mathrm{Kg} / \mathrm{cm}^{2}$ & Dataskar ${ }^{20}$ \\
\hline
\end{tabular}

Das et al., ${ }^{14}$ mentioned about bamboo huts and houses in the North-eastern part of India. The height of the plinth of bamboo huts is about $500 \mathrm{~mm}$, which is made of rammed earth. Sliced bamboo strips are treated with a mixture of mud, cow-dung, chopped straw to protect against microbial attack. It has been found that the structural soundness of prefabricated and treated bamboo products is high and is reported to be an excellent substitute of timber. The bamboo houses are also mentioned to be earthquake resistant. Being a low cost material, requiring simple construction techniques bamboo is compliant with the fundamental requirements for an ideal building material. The bamboo based houses are reported to have a scope for immense implementation. The market for green building materials is wide. Buildings with green roof top are reported to consume much less energy than conventional building materials. ${ }^{15}$ Integrating bamboo with conventional materials of construction would not only provide comfortable temperature zone inside the house, but also reduce indoor air pollution and energy consumption.

\section{Challenges for wider utilization of bamboo}

Bamboo culm offers a distinct possibility for mass housing while actively contributing to the eco-restoration, carbon credits and livelihoods of the disadvantaged rural communities. Bamboo species with high lignin content is desirable for housing, and undesirable for paper Industry. ${ }^{16}$ Therefore, the study of physico-chemical properties of various bamboo species is important for its efficient utilization. The data for characterization of various bamboo species is scanty. Weather conditions, storage conditions and harvesting techniques affect the life span of bamboo culm, varying from 1-3 years without treatment.

Fungus, termite, borer beetles are the main destroyer of both wood and bamboo in storage. ${ }^{6}$ Brown rot fungi like G. trabeum, P. placenta, P. monticol and white rot fungi like T. versicolor, C. versicolor, $P$. versicolar, bacteria and subterranean termites deteriorate the culm under storage, with one or more of these organisms attacking the culms in the succession. ${ }^{16}$ There are certain chemical preservatives, that are used by local artisans as well as industry to improve the shelf life of bamboo culms. About two third of the wood preservation industry uses CCA preservative. Other commonly used chemicals are Pentachlorophenol (PCP), Boric acid-Borax, Zinc naphthenate,
Copper naphthenate, Tebuconazole, IPBC (3-iodo 2-propanyl butyl carbamate), Chlorothalonil, Isothiozolones and synthetic pyrethroides. Boron compounds are safe but they are soluble in water, thus are easily leachable. Effluent containing CCA and CCB, needs to be treated before disposal. Most conventional preservatives are implicated in environmental pollution, and a few of them may be harmful to human health also. ${ }^{6,17,18}$

There are certain traditional treatment techniques like water leaching and smoke treatment, which have been scientifically validated under laboratory conditions. ${ }^{19}$ Green preservatives which are based on plant products needs to be employed in the large scale treatment of bamboo under storage conditions. ${ }^{20}$

\section{Conclusion}

Bamboo is a grass with enormous potential to be utilized in building and construction industry. There are plenty of resources for the plant available globally. There are certain unique features associated with bamboo like its exceptionally high growth rate, earthquake resistant properties, etc. However, its poor decay resistance restricts its usage to handicraft items and tools only. There is a strong need to develop the eco-friendly preservatives for improving the shelf-life of bamboo and its product so that bamboo can become an attractive material for housing and building industry.

\section{Acknowledgements}

None.

\section{Conflict of interest}

Author declares that there is no conflict of interest.

\section{References}

1. Lobovikov M, Paudel S, Piazza M. Non wood forest products, World bamboo resources, a thematic study prepared in the framework of the Global Forest Resources Assessment 2005. China: INBAR publication; 2005

2. Bystriakova N, Kapos V, Lysenko I. Bamboo biodiversity: Africa, Madagascar and the Americas. UK: UNEP; 2004.

3. FAO. Global forest assessment Report. Italy: FAO; 2010

4. Song XZ, Zhou GM, Jiang H, et al. Carbon sequestration by Chinese bamboo forests and their ecological benefits: Assessment of potential, problems, and future challenges. Environmental Reviews. 2011;19:418428

5. Forest Survey of India (FSI). India State of Forest Report, 2011. The Ministry of Environment and Forests, Government of India.

6. Liese W, Kumar S. Bamboo preservation compendium. China: INBAR publication; 2003. p. 37-106.

7. Kaur PJ, Satya SS, Pant KK, et al. Bamboo: The material of future. International Journal Series in Multidisciplinary. 2016;2(2):27-34.

8. Scurlock JMO, Dayton DC, Hames B. Bamboo: an overlooked biomass resource? Biomass and Bioenergy. 2000;19(4):229-244.

9. Bhalla S, Gupta S, Gudhakar P, et al. Bamboo as green alternative to concrete and steel for modern structures. Journal of Environmental research and development. 2008;3(2):362-370.

10. Ibe AE. Sustainable forest Resources management for Rural Livelihood and food security in Imo State, Nigeria. In: research for Development (R4D) Responses to Food security and Poverty reduction in Africa. 2013. p. 239-252. 
11. Nwaihu EC, Egbuche CT, Onuoha GN, at al. Socio-Economic Importance and Livelihood Utilization of Bamboo (Bambusa vulgris) in Imo State Southeast Nigeria. Agriculture, Forestry and Fisheries. 2015;4(3-1):81-85.

12. Ghavami K. Ultimate load behaviour of bamboo reinforced lightweight concrete beams. Cement and Concrete Composites. 1995;17(4):281288.

13. Ghavami K. Bamboo as reinforcement in structural concrete elements Cement \& Concrete Composites. 2005;27(6):637-649.

14. Das S, Mukhopadhy P. Multi-hazard disaster resilient housing with bamboo-based system, $7^{\text {th }}$ International Conference on Building Resilience; Using scientific knowledge to inform policy and practice in disaster risk reduction, ICBR2017, 27-29 November 2017, Bangkok, Thailand. Procedia Engineering. 2018;212:937-945.

15. Haong CP, Kinney KA, Corsi RL. Ozone removal by green building materials. Journal of Building and Environment. 2009;44(8):16271633
16. Kaur PJ, Kardam V, Pant KK, et al. Characterization of commercially important Asian bamboo species. European Journal of wood and Wood Products. 2016;74(1):137-139.

17. Schultz TP, Nicholas DD, Preston AF. A brief review of the past, present and future of wood preservation. Pest Management Science. 2007;63(8):784-788.

18. Evans P. Emerging technologies in wood protection. Forest Products Journal. 2003;53(1):14-22.

19. Kaur PJ, Pant KK, Naik SN, et al. Chemical characterization and decay resistance analysis of Smoke treated bamboo species. European Journal of wood and Wood Products. 2016;74(4):625-628.

20. Dange S, Pataskar SV. Cost and Design Analysis of Steel and Bamboo Reinforcement. International Journal of Innovative Research in Science, Engineering and Technology. 2017;6(12):22464-22477. 